\title{
Integration of Work and Leisure in the Performance of Spoken Word Poetry in Kenya
}

\author{
Beatrice Jane Ekesa (Corresponding author) \\ Department of Literature, Faculty of Arts, University of Nairobi, Kenya \\ Email: bettyekesa@yahoo.com
}

Received: 27/06/2020

Accepted: 08/08/2020

Published: 01/09/2020

Volume: 1 Issue: 3

How to cite this paper: Ekesa, B. J. (2020). Integration of Work and Leisure in the Performance of Spoken Word Poetry in Kenya. Journal of Critical Studies in Language and Literature, 1(3), 9-13

DOI: https://doi.org/10.46809/jcsll.v1i3.23

Copyright (C) 2020 by author(s) and Global Talent Academy Ltd. This work is licensed under the Creative Commons Attribution International License (CC BY 4.0).

http://creativecommons.org/licenses/by/4.0/

\section{(c) (i)}

\begin{abstract}
Spoken word poetry, an emerging genre in Kenyan literature, is popular among the urban population. The performance of this creative work draws audience from different socio-economic backgrounds who view it as a source of entertainment. Majority of these poets begin off by staging performances in order to exercise their talents and entertain their audience without financial gain. However, once they get the desired popularity, their interests change and they begin to view the performance of spoken word poetry as an alternative source of income. It is against this background that this paper seeks to explore the relationship between work and leisure in the performance of spoken word poetry in Kenya. Scholars in the field of leisure studies are constantly seeking the relationship between work and leisure. This research seeks to examine the representation of labour and leisure in the creative industry of spoken word poetry in Kenya. The study explores the characteristics of work and leisure to determine the leisure/work relationship in the performance of spoken word poetry in Kenyan literature.
\end{abstract}

Keywords: Work, Leisure, Continuum, Spoken Word, Performance Poetry

\section{Introduction}

Richard Florida (2002), in his thesis talks about the emerging 'creative class' and its role in promoting strategies for urban development based on the stimulation of creative industries. Neil Ravenscroft and Paul Gilchrist use Richard Florida's thesis to talk about how the rising "creative class' brings forth a new lifestyle which they refer to as the "working society of leisure", where work and leisure are related. They use their interviews with creative workers to assert that the working society of leisure lifestyle can only work for those who are ready to take economic risks because they have enough resources. In this assertion, Ravenscroft and Gilchrist look at the rising "creative class" as a preserve of the rich who can afford to venture into creative activities while working because they are wealthy and they can afford to shift their focus from work at times to explore their creative skills without putting their businesses in jeopardy. While the "working society of leisure" lifestyle does not resonate with that of the majority of the spoken word poets in Kenya since most of them have not yet made enough resources to afford them such a privilege, this study examines how leisure and work are intertwined in this emerging genre in Kenya. Most of these spoken word poets engage in the art form for the love of it, as well as for the financial gain that comes 
with it. Most of these spoken word poets engage in the art form for the love of it, as well as for the financial gain that comes with it. Most of them start off without any resources as outlined by Ravenscroft and Gilchrist, but they are still ready to take economic risks by combining work and leisure in their creative works. They venture into self-employment by performing and self-publishing their work on the various social media sites at their disposal. This gives them a "higher job satisfaction than regular employees" (Benz \& Frey, 2004, P.96).

\section{Leisure and Work as a Continuum}

Wilensky, (1960) views leisure as a continuation of work. This means that there is no clear cut distinction as to where leisure/work begins and ends. This study investigates how work and leisure can be viewed as part of a continuum through the work of eight spoken word poets that I interviewed during my previous research entitled, "Heterogeneity and Performance of Spoken Word Poetry in Kenya" (p. 451). McRobbie (2002) asserts that creative works are hybrid in nature and that they 'disrupt' the traditional division between leisure and work. The line between leisure and work is blurred when placed in the context of creative works where it is problematic to point out where work ends and where leisure begins. The spoken word poets that I have personally interacted with draw a very thin line between leisure and work in relation to their creative works. As earlier stated, most of them perform and self - publish their creative work on social media which classifies it as leisure since they are in charge of the time they spent. However, there are times when they will be on a Television show to entertain the audience without the full control of how they spend their time because the producer and the director of the programme will determine how they spend their time on the show. During these television shows the poets are under the authority of others hence their performances can viewed as work. "Leisure may be defined as the time that is under the control of the individual ... work can be defined as time that is under the control of others," (Zerubarel, 1981, P.46). The performance of spoken word poetry can be viewed both as work and leisure depending on personal experiences of the poets under investigation.

Neulinger (1981) views work and leisure as part of a continuum. Neulinger's psychological model is important in distinguishing leisure and work experiences in order to establish how they are interrelated. According to Neulinger's model, perceived freedom is the basis for leisure while perceived constraint is the basis for work. Leisure and non-leisure can be distinguished in the dimension of perceived freedom and on whether the motivation is intrinsic or extrinsic. Stebbins (1992) came up with the phrase "serious leisure" to refer to those activities that are freely chosen, which require effort and commitment and for which there are extrinsic reasons to participate. To this end spoken word poetry could fit the "serious leisure" brand if we consider the fact that the poets' engagement in this genre is a matter of personal choice, but once they immerse themselves in it, effort and commitment must be demonstrated to remain relevant. It is at this point that the line between leisure and work becomes obscure. A good example of how this works for most of these spoken word poets is their use of social media as a marketing strategy for their poetry.

Originally social media platforms like Facebook, YouTube, Instagram and Twitter, were viewed as entertainment spots for a number of users, including the spoken word poets, which made their poetry on such platform to acquire a leisure-like status. However, these poets are using the same platforms to market themselves to prospective advertising companies that may want to use their popularity to advertise their products. As a result, a platform that was initially meant to entertain friends has ended up being a business venture for these poets, hence making this genre a perfect example of how work and leisure can coexist. Long before the advancement of technology, scholars had already predicted the ease with which work could be completed by making use of technology. Maynard Keyne $(1930,369)$ was of the view that "technology can dispense with most work." However his main concern was if human beings will manage the "abundance of leisure" that comes with such technological advancement. According to him technology will make work easier and therefore create a lot of free time for the workers which may kill the spirit of real hard work.

Mei-Ling Chien (2015) explores the dialectical relationship between leisure and work. He uses mountain songs in Taiwan to show the binary between leisure and work. He asserts that leisure and work are "one while opposite to one another." In reference to mountain songs, Chien concludes that there are times when "The songs complimented work, while at other times they were separate from work." (p. 57). In this regard, Chien acknowledges the thin line that exists between leisure and work. He views leisure and work as a continuum in relation to the mountain songs that were sung while working in the fields. However he also points out that leisure and work can be "separable" and "unrelated." While Chien explores the relationship between work and leisure by looking at what the singers are doing while working, my paper seeks to establish the relationship between work and leisure in terms of the monetary benefits that the spoken word poets get as a result of using their talent to entertain the audience both in theatrical performances and on social media platforms.

Yechezkel Israeli and Dalit Gasul, draw the relationship between work and leisure when talking about mountain biking in Israel. They state that most cyclists begin as "amateur cyclists" and in time become more skilled, leading to what they term as "serious leisure" trends, which lead most governments to enforce cycling tourism (Israeli \& Gasul, 2019). Elkington and Stebbins (2014) define "Serious leisure as a permanent and focused involvement with amateur..., ongoing and interesting leisure activity...in a way that allows the participant to develop expertise in learning and executing the required special skills, knowledge and experience" (Cited in Israeli \& Gasul, 2019, p.181). This resonates with spoken word poets in Kenya who also begin as amateur poets in their performances, but improve their skill as they gain more experience in the field. In their 
amateur state, these poets perform in public spaces for free, but as they perfect their skill they start charging entry fee to their performances.

This paper classifies spoken word poets into two categories based on the amount of time they spend in the preparation and dissemination of their poetry. Thus we have the full time and part-time spoken word poets. In my classification, the full time spoken word poets are those who rely entirely on their performances to earn a living. This category includes poets like Dorphan (Dennis Mutuma), Kennet B. (Kennedy Odongo) and Mufasa (Ken Kibet). The part- time spoken word poets are those who use their poetry as a part-time activity that they engage in to entertain their audience as well as supplement their income. This category involves artists who are involved in other careers but view spoken word poetry as a part time job which they undertake outside their working hours. This category includes poets like Namatsi Lukoye, Wanjiku Mwaura, Raya Wambui and Brigeddia Poet. Therefore, the terms full-time and part-time spoken word poets are used in this paper to refer to the two categories of spoken word poets in Kenya. This study intends to explore how these two types of spoken word poets manage to integrate both work and leisure in their performances.

\subsection{Full time Spoken word Poets}

The full-time spoken word poets in Kenya are self-employed hence they enjoy perceived freedom in the course of their performances. However, their motivation is extrinsic because they use their creative works to generate income. Roadburg (1983) carried out some research work on paid and unpaid soccer players and discovered that the paid soccer players perceived the activity as work while the unpaid players perceived it as leisure. Similarly, the full-time spoken word poets consider their creative works as work since they expect to earn a living from their performances, while at the same time enjoying perceived freedom which is the basis for leisure. "Preference for leisure" is given as one of the reasons why people opt to retire from employment (Mao, Ostaszewski \& Wen, 2019). This is viewed in the light of those who pursue occupations that are considered as work in this study, and are expected to retire from active duty at some point, as they advance in age. However, in this paper, leisure and work are intertwined. According to Nels Anderson (2002), leisure is best understood against the background of work. He views work as "time given to a job, for which one is paid." Payment for the spoken word poets comes in the form of the money they collect from the audience before the performance. Most of the spoken word poets in Kenya charge a fee during their live performances at venues such as Alliance Francaise and Goethe Institute in Nairobi Kenya. In the light of Anderson's definition of work, therefore, all the full time spoken word poets in this paper use their performances as work. Besides, these poets also generate income using the poetry they disseminate via social media platforms like YouTube, Facebook, Twitter, and Instagram by ensuring that they maintain a big audience through the number of likes, views, and comments left on their pages and blogs. To this end, the performance of spoken word poetry can be viewed as "serious leisure" because it constitutes a social reward, which is, belonging to a "social network" (Israel \& Gasul, 2019).

In addition, Brook (1993) drew some distinction between work and non-work using managers' experiences. She discovered that both work and non-work have some similarities in terms of creativity and self-development, but established that non-work has additional characteristics like freedom of choice, socially-oriented and discretionary. Spoken word poetry in Kenya integrates both work and leisure because the full-time spoken word poets have to be creative to compose and perform their poems to the audience, and they also rely on their art to earn a living. On the other hand, these poets have the freedom to participate in these performances which are performed before social gatherings at the poet's discretion. Worth noting is the fact that a vast majority of the spoken word poets are self - employed. This ensures that they are their own boss. Matthias Benz and Bruno Frey (2004, 95-134) assert that "Self - employment is one way to avoid control by others..." This in turn results into "A higher job satisfaction" when compared to workers who are under the control of others. The same can be said of the spoken word poets in Kenya. Most of them are happy and contented with their work.

Dorphan, whose real name is Dennis Mutuma, is a full-time spoken word poet who is self-employed and relies on the various shows he stages across the country to earn a living. He gained fame into the spoken word arena after winning the $34^{\text {th }}$ poetry slam Africa, a poetry competition which attracts participants from all over the world, especially those from Africa. Currently, he is one of the organisers for the Poetry Slam Africa, alongside other poets. One of his poems entitled "Najua", is creatively composed to articulate the concerns of young poets who struggle with their creative works to make ends meet. This poem paints the real picture of how these poets struggle to raise funds in order to have their creative works reach their audience expecting to earn money from it but sometimes get disappointed when the organisers decide not to pay them. Most of his performances are advertised on social media platforms like YouTube, Facebook, Twitter and Instagram, and tickets sold to potential audiences. It is from these proceeds that the poet earns his income. He also records and uploads his performances on YouTube which is also another source of income for his poems. Some of his spoken word poems available on YouTube are "Nyota Yangu", "Mum Aliishia" and "Najua". Dorphan also performs for leisure for friends during social gatherings. This brings in the component of spoken word poetry as volunteer work. According to Yoram Weiss (2009), "Volunteer work" collapses the boundary between work and leisure. He asserts that voluntary work is viewed as leisure when we consider the fact that the worker is free to decide whether they want to participate or not. On the other hand it is viewed as work because others get paid where one is called in to volunteer. If we look at it in the case of the spoken word poets who are called to volunteer their creativity in some events, it can be viewed as leisure because they participate in such forums by choice, yet other artists might charge a fee for such entertainment.

Kennet B., whose real name is Kennedy Odongo, is yet another full time spoken word poet who balances between work and leisure during his performances. Most of his poems are creatively composed to address the theme of environmental 
conservation. He has recorded most of his poems on DVDs which he sells to his audience in order to earn a living. He also presents his poetry on YouTube and Facebook. He is also invited to perform his poetry during several functions across the country at a fee. He also provides a platform for amateur spoken word poets at the Kenya Cultural Centre and the Kenya National Theatre. The audience does not pay any fee to attend the performances. In fact, free lunch is provided to attract more spectators to the event. Once the amateur spoken word poets gain popularity and become more skilled, they venture out to other venues where they begin charging entry fee for their performances. Henceforth, they engage in the performance of spoken word poetry as "serious leisure," which is rewarding and provides a source of identity to the poets as they form social relationships with other poets and members of the audience. (Israeli \& Gasul, 2019)

He also hosts a poetry and comedy show at the Kenya Cultural Centre dubbed "Poetry After Lunch". This show helps to nurture upcoming poets and comedians. This is a good example of leisure because he does not charge a fee for this event. In fact, he provides free meals to both the participants and the audience before the performances. His poetry is also featured on several radio programmes such as Citizen Radio's "Mseto Extra" and KBC's Mayenga FM.

Mufasa, whose real name is Ken Kibet, is also a full time spoken word poet who relies on his creativity to earn a living. He is one of the most celebrated spoken word poets, popularly referred to as the king of spoken word in Kenya. He attracts a huge audience during his performances which sees him earning a huge income from his art. He also gets more income by selling his recorded videos to his audience. He is also a committee member and a judge at the Poetry Slam Africa which helps him nurture upcoming poets while at the same time earning an income. Mufasa's poetry is rated highly with over one thousand followers both on Facebook and YouTube. This is a good income generating venture to an otherwise leisurely activity.

\subsection{Part time Spoken Word Poets}

The part time spoken word poets, just like the full time spoken word poets, integrate work and leisure in the course of their performances. Although they are engaged in other career paths, they are motivated into the field by their love for spoken word poetry as well as the financial benefits they gain from it. Therefore, as far as spoken word poetry is concerned whether full time or part time there is the aspect of self - employment on the part of the poets.

Namatsi Lukoye works full time as a public relations officer for Cerebral Palsy Society of Kenya. However, during her free time she composes and performs spoken word poetry to her audience in order to supplement her income. Sometimes she uses her poetry to advocate for the rights of persons living with disabilities as well as source for donor funding.

Raya Wambui is the manager at Pet Spa in Nairobi but still manages to perform her poetry to the audience. She gained fame into the spoken word realm when she participated in the Poetry Slam Africa and was crowned the queen. She performs her poetry on various platforms in which the members of the audience have to pay to watch her.

Wanjiku Mwaura works full time with the Deutsche Welle Media Company in Germany, but her love for poetry has seen her perform on various platforms as well as publish a poetry anthology entitled The Flow of my Soul. She shot into fame when she was crowned the 9th Poetry Slam African Queen. She earns an extra income through her creative works by staging various spoken word poetry performances and also by selling her poetry book to the audience.

By the time of my research, Brigeddia Poet, whose real name is Francis Onono, was working full time as a forest ranger in Kenya. He also works as a part time spoken word poet due to his love for poetry, and the income he raises from the various performances acts as a motivating factor. He also performs on "Churchill Live" at a fee, and has her poetry published on social media platforms like Facebook, YouTube, Instagram and Twitter.

\section{Conclusion}

Spoken word poetry should not only be viewed through the lens of entertainment where relaxation is the main focus, but also as an income generating activity where hard work and commitment is required. The poets no longer engage in this creative art as a pass time activity but as an alternative way of earning a living. Newman (1983) asserts that relaxation and self-expression is not the only thing that characterise leisure. The performance of spoken word poetry in Kenya helps us to view work and leisure as a continuum. Both the full time and part time spoken word poets in Kenya view this art form as an integration of both work and leisure and it should therefore be viewed as an alternative form of self-employment to the urban population who form a big percentage of the unemployed.

\section{References}

Anderson, N. (1961). Work and leisure in Literature. Routledge and Kegan Paul Ltd, London.

Benz, M., \& Frey, B. (2004). Being Independent Raises Happiness at Work. Swedish Economic policy Review, $11,95-134$.

Brook, J.A. (1993). Leisure Meanings and Comparisons with Work. Leisure Studies, 12, 149-162.

Chien, M. (2015). Leisure, Work, and Constituted Everydayness: Mountain Songs of Hakka Women in Colonized Northern Taiwan. Asian Etymology, 74 (1), 37-62.

Florida, R. (2002). The Rise of the Creative Class and how it's Transforming Work, Leisure, Community and Everyday Life. New York: Basic Books.

Israeli, Y., \& Gasul, D. (2019). Od Ozbiljnog Slobodnog Vremena Do Cikloturizma - Slucaj Brdskog Biciklizma - From Serious Leisure to Cycling Tourism - The Case of Mountain Biking. Acta Turistica, 31(2), 179-211. 
Mao, H., Ostaszewski, K., \& Wen, Z. (2019). The Retirement Decision with Consideration of Part-Time Work after Retirement. Journal of Insurance Issues, 42 (1), 86-112.

McRobbie, A. (2002). "Clubs to Companies: Notes on the Decline of Political Culture in Speeded Up Creative Worlds," Cultural Studies, 16,516 -531.

Neulinger, J. (1981). The Psychology of Leisure. Springfield: Charles C. Thomas. (1981). To Leisure: An Introduction. Boston: Allyn and Bacon.

Newman, O. (1983). The Coming of a Leisure Society? Leisure Studies, 2, 97-109.

Ravenscroft, N., \& Gilchrist, P. (2005). Post-Fordist Restructuring and Vocational Training in Sport in the UK. Managing Leisure, 10, 166-183.

Roadburg, A. (1983). Freedom and Enjoyment: Disentangling Perceived Leisure. Journal of Leisure Research, 15, $15-26$.

Stebbins, R. (1982). Serious Leisure: A Conceptual Statement. Pacific Sociological Review, 25, 251-272.

Stebbins, R. (1992). Amateurs, Professionals, and Serious Leisure. Montreal, McGill-Queen's University Press.

Weiss, Y. (2009). Work and Leisure: A History of Ideas. Journal of Labour Economics, 27 (1), 58-89

Wilensky, H. L. (1960). Work, Careers and Social Integration. International Social Science Journal, 12, 543-560.

Zerubarel, E. (1981). Hidden Rhythms. Berkeley: University of California Press. 